\title{
Management of health risks associated with oysters harvested from a norovirus contaminated area, Ireland, February-March 2010
}

B Doré (bill.dore@marine.ie) ${ }^{1}$, S Keaveney ${ }^{1}$, J Flannery ${ }^{1}$, P Rajko-Nenow ${ }^{1}$

1. Marine Institute, Galway, Ireland

Citation style for this article:

Citation style for this article: Doré B, Keaveney S, Flannery J, Rajko-Nenow P. Management of health risks associated with oysters harvested from a norovirus contaminated area, Ireland, February-March 2010. Euro Surveill. 2010;15(19):pii=19567. Available online: http://www.eurosurveillance.org/ViewArticle.

aspx?Articleld $=19567$

This article has been published on 13 May 2010

Oysters from a harvesting area responsible for outbreaks of gastroenteritis were relaid at a clean seawater site and subsequently depurated in tanks of purified seawater at elevated temperatures. This combined treatment reduced norovirus levels to those detected prior to the outbreak. On the basis of norovirus monitoring the sale of treated oysters was permitted although the harvest area remained closed for direct sale of oysters. No reports of illness have been associated with the consumption of treated oysters.

Oysters are filter-feeding bivalve molluscs which may become contaminated with human pathogens when grown in sewage-contaminated waters, which can lead to illness as the oysters are often consumed raw. In Europe, regulations are in place to prevent this risk [1]. Shellfish harvesting areas are classified into three categories (A, B or C) depending on the extent of faecal contamination of the area as judged by levels of Escherichia coli. Shellfish treatments are prescribed depending on the classification. Despite these controls outbreaks of illness associated with oyster consumption continue, in particular outbreaks of gastroenteritis associated with norovirus (NoV)-contaminated oysters. Until recently, suitable methods for the quantitative detection of NoV in shellfish have not been available. A high prevalence of NoV in oysters from a range of harvesting areas throughout Europe has been shown by PCR [5-7]. Quantitative real-time PCR procedures are currently undergoing standardisation at the European level (CEN WG6 TAG4). Where quantitative data exists, NoV levels detected in shellfish harvest areas are often low and near the detection limit $[8,9]$. The public health significance of oysters containing low levels of NoV is unclear.
Various intervention steps are available to reduce the microbiological load in sewage-contaminated shellfish. These include relaying shellfish in clean seawater areas to allow them to purge contaminants. A similar, more controlled process is performed in tanks of seawater purified by disinfection. This process is called depuration and is used extensively throughout Europe. Depuration is commonly carried out for 24 to 48 hours at ambient temperatures. It has been demonstrated to eliminate bacteria from shellfish but has little impact on virus levels in oysters [10,11]. However, depuration carried out at elevated temperatures $\left(17-20^{\circ} \mathrm{C}\right)$ for extended periods of three to five days reduces virus levels in oysters significantly $[12,13]$.

NoV generally causes a relatively mild gastroenteritis in most people that is significantly under-reported and often recognised only in outbreak situations. In recent months an unusually high number of NoV gastroenteritis outbreaks associated with the consumption of shellfish have been reported in Europe [14]. It is likely that the recent high incidence of oyster-associated outbreaks with is connected the unusually cold weather in 2010.

\section{Norovirus outbreaks}

Over a five week period in January and February 2010, more than 70 cases of gastroenteritis in Ireland and the United Kingdom (UK) were due to the consumption of oysters originating from an Irish harvesting area. The infections in England have been recorded as part of a wider report on European-wide outbreaks [14]. Oysters connected to two illness incidents in Ireland were available for testing and contained 2,040 and 2,350 NoV genome copies per g, respectively.

TABLE

Norovirus GII levels in oysters from the harvest area, Ireland, 2009

\begin{tabular}{|c|c|c|c|c|c|c|c|c|}
\hline Date 2009 & $20 / 01$ & $25 / 02$ & $26 / 04$ & $19 / 05$ & $05 / 07$ & $11 / 08$ & $09 / 11$ & $13 / 12$ \\
\hline Genome copies per g & 219 & ८LOQ & $<L O Q$ & ND & ND & ND & 1,280 & 278 \\
\hline
\end{tabular}

LOQ: limit of quantitation (100 virus genome copies per g); ND not detected. 
Following reports of illness two companies producing oysters from the affected harvest area voluntarily ceased production on 10 February and implemented a recall of product already on the market. On 12 February a formal compliance notice was issued by the competent authority in Ireland the harvest area was closed for direct sale of oysters. Prior to the outbreak limited data was available regarding NoV levels in oysters from this harvest area which to our knowledge was not associated with any reports of illness in 2009.

We report the use of relaying combined with extended depuration at elevated temperatures to reduce NoV in oysters of the harvesting area and highlight the potential of quantitative real-time PCR for monitoring treatment processes for oysters and more accurately assess the risk to consumers.

\section{Methods}

\section{Treatment and sampling}

On 26 February oysters from the harvest area were relaid in an area believed to be free from sewage contamination. Relaid shellfish were monitored for NoV levels at least once a week. On 15 March oysters from the relay site were further treated by depuration at elevated temperature $\left(15-17^{\circ} \mathrm{C}\right)$ for a period of at least four days. Subsequent batches of relaid shellfish were depurated using the same treatment regime.

Samples of 24 whole oysters were transported to the laboratory within 24 hours of sampling under chilled conditions and analysed for NoV genogroup I (GI) and genogroup II (GII) within 24 hours of receipt in the laboratory.

\section{Detection and quantification of} norovirus by real-time PCR

Virus extraction was undertaken as described previously [15] followed by RNA extraction based on the Boom method [16] using NucliSens Magnetic Extraction reagents (Biomerieux). NoV RNA was then detected by reverse transcription (RT) quantitative real-time PCR employing primers and probes specific for NoV GI $[17,18]$ and GII $[19,20]$. Real-time PCR controls were used to evaluate extraction efficiency [21] and amplification efficiency $[17,18]$.

\section{Results}

During 2009, eight samples of oysters from the area had been analysed for NoV. These data had been collected retrospectively as part of a wider survey to determine background levels of NoV in shellfish harvest areas and results were not intended for regulatory control. Levels ranged from not detectable to 1,280 viral genome copies per g (Table).

Throughout the period of NoV monitoring following the outbreak in February and March 2010, NoV GI was detected in two samples from the harvest area. On both occasions levels were below the limit of quantitation of the assay (100 viral genome copies per $\mathrm{g}$ ). NoV
GI was not detected in any samples from the relay site or in samples taken during the depuration period.

NoV GII levels in nine samples of oysters from the harvest area between 9 February and 15 March 2010 are shown in Figure 1. During this period in the norovirus load in the oysters did not decrease and ranged from 1,100 to 2,900 viral genome copies per $\mathrm{g}$.

In oysters relaid from the harvest area to clean seawater, NoV GII levels decreased from 2,900 to 492 viral genome copies in a 17-day period from 26 February to 15 March (Figure 2). Subsequent depuration of the relaid shellfish at $17{ }^{\circ} \mathrm{C}$ reduced NoV GIl levels to 136 viral genome copies per $\mathrm{g}$ after four days and to below the limit of quantitation of the assay (100 viral genome copies per $\mathrm{g}$ ) after six days.

Subsequently, during the period from 29 March to 12 April, a further four batches of oysters which had been relaid since the 26 February have been depurated. Each depuration cycle was performed for between four and eight days at temperatures between 15 and $17{ }^{\circ} \mathrm{C}$ and reduced the levels of NoV GII to below 200 viral genome copies per $\mathrm{g}$.

\section{FIGURE 1}

Norovirus levels in oysters from the main harvest area, Ireland, 9 February-15 March 2010

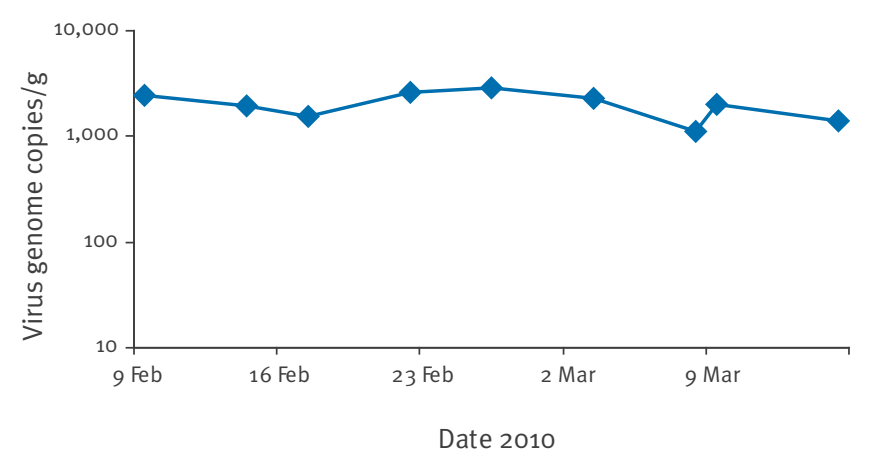

\section{FIGURE 2}

Norovirus levels in oysters from the main harvest area during treatment by relaying and depuration, Ireland, 9 February-15 March 2010

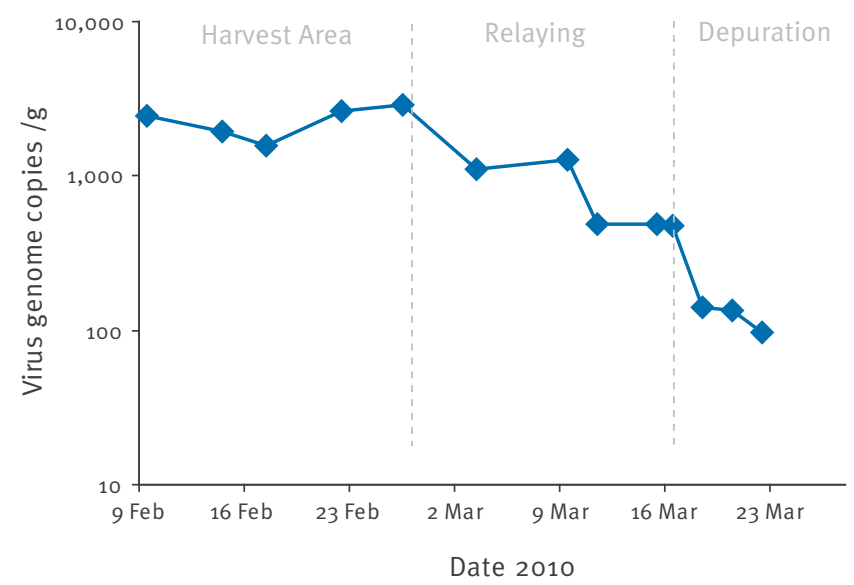




\section{Discussion}

The oysters responsible for the outbreak described here originated from a category A classified water with $E$. coli levels consistently below 230 MPN (most probable number) per $100 \mathrm{~g}$. Oysters from category $A$ areas are approved for consumption without treatment. In practice, oysters from this harvest area were depurated at ambient temperature before sale. However it is well documented that depuration at low temperatures has little impact on reducing virus levels in shellfish $[10,22]$. The recent outbreaks of NoV infection associated with consumption of oysters from this harvesting site confirm the inadequacy of the current control measures and treatment processes to fully protect consumers in Europe.

Low levels of NoV are commonly detected in oysters, particularly during the winter months. A limited data set from 2009 suggests that NoV levels in oysters from the harvest area in question are also generally low. No reports of illness associated with this area were recorded during this period. In January and February 2010 however, the levels of NoV increased significantly, probably due to the seasonally high level of the virus in the human population and the particularly cold temperatures. This increase in NoV levels was clearly associated with outbreaks of NoV gastroenteritis in consumers. In response the competent authorities in Ireland closed the harvest area for direct sale of oysters and it remains closed at the time of publication of this report.

To facilitate the sale of oysters from the harvest area, treatment options were considered and validated by real-time PCR monitoring. Previous studies have demonstrated that NoV may persist following treatment such as relaying and depuration $[10,22]$. The data presented here demonstrate that relaying of oysters for 17 days in a clean seawater site followed by a minimum of four days purification at temperatures of $15-17^{\circ} \mathrm{C}$ reduced the NoV load to background levels detected in the harvest area before the gastroenteritis incidents. On this basis the risk to consumers was considered negligible, and while the main harvest area remained closed for direct sale, oysters treated in the described way since 26 February have been allowed on the market. Since 19 March 2010 more than 50,000 oysters have been placed on the market and no reports of illness have been received. NoV levels in these batches were less than 200 viral genome copies per $\mathrm{g}$.

Limited data are available on the levels of NoV in oysters that have caused outbreaks. Recently two reports of large outbreaks have demonstrated high NoV levels (possibly $>8,000$ viral genome copies per $\mathrm{g}$ ) in oysters from the harvest areas involved [9,23]. Although the NoV dose required to cause infection may be as low as 10 to 100 infectious particles [24] and sporadic cases may be caused by oysters with low NoV levels, the two reports and our results would suggest that relatively high levels of NoV (possibly $>1000$ viral genome copies per g) are required to cause significant outbreaks of illness. This may be consistent with a dose response pattern described in human volunteer studies investigating Norwalk virus (GGI.I) that indicated that $3.24 \times 103$ genome copies of NoV GGI.I were required before illness was observed [25]. In addition it has been suggested that PCR may overestimate the level of viable virus particles in shellfish and this should be taken into account when considering the risk associated with oyster consumption. There is growing evidence that it is possible to distinguish the relative risk of illness based on the level of NoV in the oysters. Given the current inadequacy of controls based on $E$. coli standards we believe that the introduction of an appropriate virus standard would have a positive public health benefit.

We believe that NoV monitoring of at-risk oyster harvesting areas and the introduction of an upper limit for NoV in oysters could prevent a significant number of outbreaks associated with oyster consumption in Europe. Validated treatment processes such as relaying and depuration at elevated temperatures can be used to produce oysters which are safe to consume despite the fact that low levels of NoV, as detected by real-time $P C R$, remain in the treated oysters.

\section{References}

1. $852 / 2004$ EN. Regulation (EC) No 852/2004 of the European Parliament and of the Council of 29th April 2004 on the hygiene of foodstuffs. Official Journal of the European Union 2004(L226):3-21.

2. Doyle A, Barataud D, Gallay A, Thiolet IM, Le Guyaguer S, Kohli E, et al. Norovirus foodborne outbreaks associated with the consumption of oysters from the Etang de Thau, France, December 2002. Eurosurveillance 2004;9(3):24-6. Available from: http://www.eurosurveillance.org/ViewArticle. aspx?Articleld $=451$

3. Le Guyader F, Bon F, DeMedici D, Parnaudeau S, Bertone A, Crudeli S, et al. Detection of multiple noroviruses associated with an international gastroenteritis outbreak linked to oyster consumption. J Clin Microbiol. 2006;44(11):3878-82.

4. Prato R, Lopalco P, Chironna M, Barbuti G, Germinario C Quarto M. Norovirus gasteroenteritis general outbreak associated with raw shellfish consumption in south Italy. BMC Infect Dis. 2004;4:37.

5. Croci L, Losio MN, Suffredini E, Pavoni E, Di Pasquale S, Fallacara F, et al. Assessment of human enteric viruses in shellfish from the northern Adriatic sea. Int J Food Microbiol. 2007;114(2):252-7.

6. Le Guyader F, Haugarreau L, Miossec L, Dubois E, Pommepuy $M$. Three-year study to assess human enteric viruses in shellfish. Appl Environ Microbiol. 2000;66(8):3241-8.

7. Formiga-Cruz M, Tofino-Quesada G, Bofill-Mas S, Lees DN, Henshilwood K, Allard AK, et al. Distribution of human virus contamination in shellfish from different growing areas in Greece, Spain, Sweden, and the United Kingdom. Appl Environ Microbiol. 2002;68(12):5990-8.

8. Keaveney S, Flannery J, Guilefoyle F, Dore, B. Preliminary results from a survey of oyster production areas in Ireland for norovirus. In: Busby $\mathrm{P}$, editor. The 6th international conference on molluscan shellfish safety; 2007; Blenheim, Marlborough, New Zealand: Royal Society of New Zealand; 2007. p. 36-40.

9. Lowther J, Avant J, Gizynski K, Rangdale R, Lees, D. Comparison between quantitative real-time reverse transcription PCR results for norovirus in oysters and self-reported illness in restaurant customers. J Food Prot. 2010;73(2):305-11.

10. Doré W, Lees D. Behaviour of Escherichia coli and Male-specific bacteriophage in environmentally contaminated bivalve molluscs before and after depuration. Appl Environ Microbiol. 1995;61(8):2830-4. 
11. Muniain-Mujika I, Girones R, Tofiño-Quesada G, Calvo M, Lucena F. Depuration dynamics of viruses in shellfish. Int Food Microbiol. 2002;77(1-2):125-33.

12. Doré W, Henshilwood K, Lees D. The development of management strategies for control of virological quality in oysters. Water Sci Technol 1998;38(12):29-35.

13. Henshilwood K, Doré W, Anderson A, Lees DN. The development of a quantitative assay for the detection of Norwalk like virus and its application to depuration. Molluscan Shellfish Safety 2003:451-65.

14. Westrell T, Dusch V, Ethelberg S, Harris J, Hjertqvist, M, Jourdan-da-Silva N, et al. Norovirus outbreaks linked to oyster consumption in the United Kingdom, Norway, France, Sweden and Denmark 2010. Eurosurveillance 2010;15(12). pii: 19524. Available from: http://www.eurosurveillance.org/ViewArticle. aspx?Articleld $=19524$.

15. Flannery J, Keaveney S, Doré W. Use of FRNA bacteriophage to indicate the risk of norovirus contamination in Irish oysters. I Food Prot. 2009;72(11):2358-62.

16. Boom R, Sol C, Salimans M, Jansen C, Wertheim-van Dillen P, van der Noordaa J. Rapid and simple method for purification of nucleic acids. J Clin Microbiol. 1990;28(3):495-503.

17. Le Guyader F, Parnaudeau S, Schaeffer J, Bosch A, Loisy $\mathrm{F}$, Pommepuy $\mathrm{M}$, et al. Detection and quantification of noroviruses in shellfish. Appl Environ Microbiol. 2009;75(3):618-24

18. Svraka S, Duizer E, Vennema H, de Bruin E, van de Veer B, Dorresteijn $\mathrm{B}$, et al. Etiological role of viruses in outbreaks of acute gastroenteritis in The Netherlands from 1994 through 2005. J Clin Microbiol. 2007;45(5):1389-94.

19. Kageyama T, Kojima S, Shinohara M, Uchida K, Fukushi S, Hoshino $\mathrm{F}$, et al. Broadly reactive and highly sensitive assay for Norwalk-like viruses based on real-time quantitative reverse transcription-PCR. J Clin Microbiol. 2003;41(4):1548-57.

20. Loisy F, Atmar R, Guillon P, Le Cann P, Pommepuy M, Le Guyager F. Real-time RT-PCR for norovirus screening in shellfish. J Virol Methods. 2005;123(1):1-7.

21. Costafreda MI, Bosch A, Pintó RM. Development, evaluation, and standardization of a real-time TaqMan reverse transcription-PCR assay for quantification of hepatitis A virus in clinical and shellfish samples. Appl Environ Microbiol. 2006;72(6):3846-55.

22. De Mesquita M, Evison L. Removal of faecal indicator bacteria and bacteriophages from the common musse (Mytilus edulis) under artificial depuration. J Appl Bacteriol. 1990;70(6):495-501.

23. Le Guyader F, Le Saux J, Ambert-Balay K, Krol J, Serais O, Parnaudeau S, et al. Aichi Virus, Norovirus, Astrovirus, Enterovirus, and Rotavirus Involved in Clinical Cases from a French Oyster-Related Gastroenteritis Outbreak. J Clin Microbiol. 2008;46(12):4011-7.

24. Kapikian A, Estes M, Chanock R. Norwalk group of viruses, p. 783-810. In: Fields B, Knipe D, Howley P (editors). Fields Virology, 3rd ed. Philadelphia: Lippincott-Raven; 1996.

25. Teunis PF, Moe CL, Liu P, Miller SE, Lindesmith L, Baric RS, et al. Norwalk virus: how infectious is it? J Med Virol. 2008;80(8):1468-76. 